\title{
DISTURBANCES CAUSED BY FLOODS IN THREE PHYSICAL PROPERTIES OF A VERTISOL SOIL IN THE EAST REGION OF CUBA, CULTIVATED WITH SUGARCANE (Saccharum spp.)
}

\author{
S. Rodríguez ${ }^{1 *}$, M. Ulloa ${ }^{2}$, Y. Pérez ${ }^{1}$, L. Rodríguez ${ }^{3}$, F. Guevara ${ }^{4}$, I. Arias ${ }^{1}$, M. Conci ${ }^{5}$, M. Tamagno ${ }^{5}$, A. Mercado ${ }^{1}$, \\ M. Travieso ${ }^{1}$, L. Tamayo ${ }^{1}$ and M. Fonseca ${ }^{3}$ \\ ${ }^{1}$ University of Granma (UDG), Cuba \\ ${ }^{2}$ Technical University of Cotopaxi (UTC), Ecuador \\ ${ }^{3}$ University of the Science and Arts of Chiapas (UNICACH), Mexico \\ ${ }^{4}$ Autonomous University of Chiapas (UACH), Mexico \\ ${ }^{5}$ National University of Villa María (UNVM). Argentina \\ srodriguezr@udg.co.cu*
}

Artículo presentado en mayo/2016 y aceptado en junio/2016

DOI: $10.15628 /$ holos.2016.4658

\section{ABSTRACT}

In Cuba the $40,3 \%$ of cultivated lands is located in poorly drained soils, with tendency to increase, compounded by the effects of current climate change, which in this region of Cuba are becoming with more frequency in extreme climatic events such as droughts and floods. The research was developed with the objective of determining the influence of flooding in a Vertisol soil in three phisycal properties in the Cauto River Valley, of the Granma province, Cuba. It was considered the presence or absence of flooding as the principal factor on large plots, each one divided into 30 plots of $48 \mathrm{~m}^{2}$, to facilitate take the replicate samples. Two
\end{abstract}

samplings, one at the beginning of the experiment and the other five months later, when the soil flooded concluded. The average of the bulk density, total porosity and aeration porosity values with their standard errors were plotted by bars, while statistically discriminated with the use of the Student $t$ test. It is concluded that prolongated water excess in the soil increased bulk density and makes it significantly decreases the total aeration and porosity, which affects physical fertility of these soils and a decrease of the sugarcane yield, the principal crop in Cuba yet.

KEYWORDS: Flooding, soil, physical properties.

\section{ALTERACIONES PROVOCADAS EN TRES PROPIEDADES FÍSICAS DE UN SUELO VERTISOL POR EFECTO DE LAS INUNDACIONES EN LA REGIÓN ORIENTAL DE CUBA, CULTIVADO CON CAÑA DE AZÚCAR (Saccharum spp.)}

\section{RESUMEN}

Se parte del hecho de que en Cuba el 40,3\% del área agrícola cultivada se ubica en suelos de mal drenaje, con tendencia al incremento, agravado por los efectos del cambio climático actual, donde en esta región de Cuba son cada vez más frecuentes los eventos climatológicos extremos como sequías e inundaciones. El trabajo se desarrolló con el objetivo de determinar la influencia que ejerce el sobrehumedecimiento del suelo en tres propiedades físicas de un suelo Vertisol del Valle del Río Cauto en la provincia de Granma, Cuba, en el cual se cultiva caña de azúcar. Se consideró el factor presencia-ausencia de sobrehumedecimiento en parcelas grandes, subdividido en 30 parcelas de $48 \mathrm{~m}^{2}$, para facilitar la toma de muestras replicadas. Se realizaron dos muestreos, uno al inicio del experimento y el otro a los cinco meses, una vez concluido el sobrehumedecimiento. Los valores promedio de la densidad aparente, porosidad total y porosidad de aireación con sus errores estándar se representaron gráficamente por medio de barras, mientras que se discriminaron estadísticamente con el empleo de la prueba t de student. Se llegó a la conclusión de que el exceso de agua en el suelo incrementa la densidad aparente y hace descender significativamente la porosidad total y de aireación, lo que afecta la fertilidad física de estos suelos, lo que provoca un descenso en los rendimientos agroindustriales de la caña de azúcar, principal cultivo económico en Cuba. Palabras claves: Sobrehumedecimiento, suelo, propiedades físicas.

PALABRAS CLAVES: Sobrehumedecimiento, suelo, propiedades físicas.. 


\section{INTRODUCCIÓN}

The soil and water resource degradation as well as the environmental contamination are perceived as the biggest problems in the tropics. There are extensive lands areas that are being subjected to the degradation in irreversible form and to degradation processes like the quick erosion, desertification, compactation, acidification, exhaustion of the natural fertility of the soil and the soil flooding. (Lal, 1994 and Rivera, 1999). The results indicate that the frequency distribution of drainage, salinity and waterlogging studies carried out in India, Australia, the USA, Pakistan, and other countries is $23 \%, 20 \%, 15 \%, 12 \%$, and $30 \%$, respectively. While frequency distribution is $45 \%, 30 \%$, and $25 \%$ for focus on salinity, comprehensive studies, and focus on waterlogging, respectively, based on the previous investigations (Valipour, 2014).

When soil is completely saturated with water is in general referred to the waterlogging. In this situation ground water is too high that it does not allow convenient agricultural activities (Sharma and Swarup, 1988).

The occurrence of soil flooding can be attributed to the retardation of water infiltration after the formation of the impermeable soil crust in the relatively lower furrow, and by reduction of RAC (Rainfall Acceptable Capacity) due to the rising of water table and heavy rainfall (Yong et al., 2011) .

Soil waterlogging governs the direction and rates of chemical, geochemical and biological reaction in the soil, indirectly these reactions may influence to the changes of soil physical properties during soil waterlogging process. The magnitude of changes are greatly influenced by many factors, such as duration of waterlogging, soil type, soil texture, and soil organic matter (Cosentino et al., 2006; Li and Shao, 2006; Bandyopadhyay et al., 2010). According to Zhang et al (2013), the temporal changes of soil physical properties in paddy soils depend not only on intrinsic soil properties but also on external hydrological condition, Goebel et al (2005), stated that soil wettability influences soil physical property such as agregate stability.

Waterlogging conditions drastically alter the soil properties, these changes in soil adversely affect the capability of a plant to survive in such situations (Dat et al., 2004). Soil waterlogging influences soil physical properties such as; lead swelling of colloids, reduce aggregate stability, and reduces permeability of soil (Ponnamperuma, 1984; Reddy and DeLaune, 2008).

Soils contain pores filled with gas and/or water. The two main gases important for respiration are

oxygen and carbon dioxide. The pathway for oxygen into the plant is from the atmosphere through soil pores to a thin water film surrounding plant root hairs. It is relatively easy for oxygen to diffuse into soil when pores are filled by air, but oxygen does not easily diffuse in water so the main constraint to oxygen movement is the thin water film surrounding root hairs. This boundary is magnified in flood/pond conditions. Carbon dioxide rarely accumulates to toxic levels in soil (Wesseling, 1974).

The loss of soil productivity by degradation processes, as excess water in the soil, has motivated many researchers from various countries of the world (Kozlowski, 1985; Dat et al., 2004; Jackson and Colmer, 2005; Irfan et al., 2010; Nickum et al., 2010; Yong et al., 2011; Ammara y Shumaila, 2012; Mahabaleshwara and Nagabhushan, 2014; Raut et al., 2014; Valipour, 2014 and 
Morales-Olmedo et al., 2015;), to develop numerous studies to quantify, in order to facilitate the selection of comprehensive conservation practices soil, for different land uses and protection (Rivera, 1999). In Australia losses due to waterlogging, were more serious than those due to soil salinity in winter cereals (Grieve et al., 1986).

In Cuba, poor drainage affects $40,3 \%$ of agricultural acreage, the estimated increase of 9,0 $\%$ over the next 15 years to be alarming (CIGEA, 2001).

The Valley of the Cauto River, in the Granma province, Cuba, is an area with edaphic and climate favourable conditions so that in certain periods of the year the soils increase the degree of saturation soil water. This valley represents $36,0 \%$ of the river basin and $31,0 \%$ of its soils is of the type Vertisol. Among the total components of the soil mass, the content of $\mathrm{MgO}$ can be superior that $\mathrm{CaO}$. Through the soil profile gleyzation symptoms are detected, the $\mathrm{pH}$ is neuter to alkaline and the cation exchange capacity and bases exchange capacity ( $40 \mathrm{me} .100 \mathrm{~g}^{-1}$ ), is high (Álvarez and Díaz, 2000). The mean annual precipitation oscillates among $800-1200 \mathrm{~mm}$ in the plain of the valley and of $2000-2200 \mathrm{~mm}$ in the mountainous zone, while the mean annual temperature of the air is between the 24 and $26{ }^{\circ} \mathrm{C}$. The values of mean annual evaporation are higher in plain areas (2 200-2 $400 \mathrm{~mm}$ ), although considerable also $(2000-2200 \mathrm{~mm}$ ) that in the mountainous zone (Álvarez and Díaz, 2000).

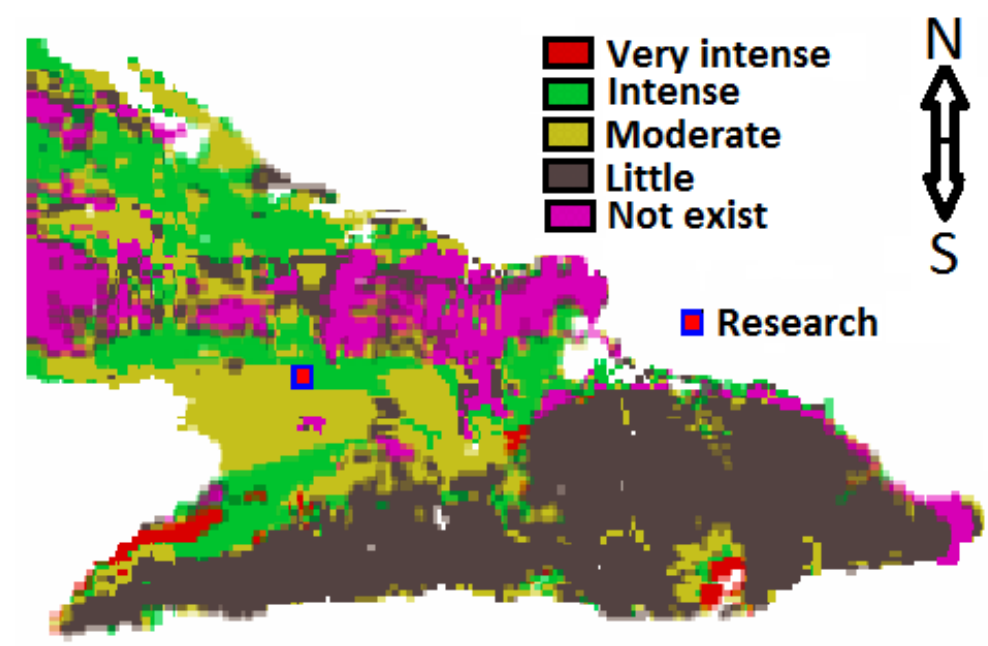

Figure 1: Flood risk map at 1,0 \% probability from physical geographical elements of eastern Cuba (sea level height , soil lithology, the inclination of the slope and the daily maximum precipitation).

A research of the representation of the Foods World Program in Cuba (PMA, 2001), it was able to capture cartographically the risk level for floods in the east region of Cuba (Fig. 1), taking into consideration important elements such as: sea level height, soil litology, the soil slope gradient and the maximum daily rainfall at $1,0 \%$ of probability.

The results, after processing the maps for each previous item was a flood hazard map 1,0 $\%$ probability (Fig.1), to emphasize that in the area of the Valley of the Cauto River belonging to the Granma province, the flood risk is moderate to severe (PMA, 2001), with the additional problem due to the effect of climate change is causing increases in extreme droughts and floods in all the world.

While there is general acceptance that climate change is driving increased flood-risk, there is still disagreement about the reliability of future predictions, particularly for sea level rise, owing 
to a lack of clear and discernable evidence for uniform worldwide changes. Prediction techniques are hampered by data limitations and an apparent reluctance to make more use of available computer models. The resulting uncertainties make it harder to develop clear and detailed policy solutions (Kenney et al., 2006).

The objective of this research was to determine the influence of the excess of water in the indicators of soil physical quality of a Vertisol soil, cultivated with sugarcane in this important agricultural area of the cuban east.

\section{MATERIALS AND METHODS}

The experiment was developed in the Sugar Enterprise "Grito de Yara", located in the Río Cauto municipality, in Granma County, Cuba (Figure 1, with the following geographic coordinates: $x 1=506,190 ; x 2=507,00 ; x 3=507,410$ and $x 4=506,550 ; y 1=218,600 ; y 2=219,140 ; y 3=218,250$ and $y 4=217,810$ ). The soil belongs to the Vertisols group according to the World Reference Base (Driessen et al., 2001); alternatively, it can be classified as a Typic Haplustert according to the Soil Survey Staff (2003).

The experiment was divides in two stage, the first stage consisted the evaluation of the physic properties soils. Were selected two big plots of 0,5 ha each one, separated to $50,0 \mathrm{~m}$ to eliminate the effect of the lateral infiltration of the water in the soil. In each one were taken three soils samples to $30 \mathrm{~cm}$ of deph. One of this plots was flooded during six months once per week and the other plot in not flooding conditions. To the six months the experiment concluded and began the taking of soils samples to determine the physical properties. Each big plot was divided into 30 plots of $48 \mathrm{~m}^{2}$, to facilitate take the replicate samples. Two samplings, one at the beginning of the experiment and the other five months later, when the soil flooded concluded. The apparent density $\left(\mathrm{g} \cdot \mathrm{cm}^{-3}\right)$, the total porosity (\%) and the aeration porosity (\%) or the porous space full with air was calculated following the methodology of Gavande (1987). Was introduced the concept of Maximum Moisture of Relative Equilibrium (Ortiz and Rivero, 2006), instead of the soil field capacity traditional, because it does not apply to this type of soil as humidity upper limit, according of the results of Cid (1992). It was considered the Productive Bondary, as the $80 \%$ of the Maximum Moisture of Relative Equilibrium.

In the second stage the experiment was carried out following the norms and procedures determined by the "Program of Genetic Improvement of Sugarcane" in Cuba, of the "National Institute of Sugarcane Research" (INICA, 2002). Each large plots one in flooded soil conditions and the other in not flooded conditions was divided in 30 small plots of $48 \mathrm{~m}^{2}$, consisting of 4 furrows of 7,5 $\mathrm{m}$ length and 1,60 $\mathrm{m}$ distance between the furrows.

Five months later, when flooded conditions concluded, both experiments (flooded and not flooded conditions) were planted at the same time with the variety sugarcane of the cuban genetic improvement program (the parentals are indicated in parenthesis) C90-469 (Ja60-5 x C87-51), Jorge et al., (2004). The experiment was started in January 2012 and the cut was realized at 12 months of age. The evaluated crop cycles were the plant cane crop (first cutting). The variables were (INICA, 2002), juice sucrose yield percent of the sugarcane (\%) using a Polarimeter, sugarcane yield in tonnes of cane per hectare $\left(\mathrm{t}\right.$ cane. $\mathrm{ha}^{-1}$ ) and agro industrial sugarcane yield in tonnes of 
sucrose concentration per hectare $\left(\mathrm{t} \mathrm{pol} . \mathrm{ha}^{-1}\right)$. The three variables were registered at the moment of cutting (12 months of age in plant cane crop).

As stress tolerance attributes, it was estimated the Stress Intensity (SI) or relative loss of the selected variable, term which appears in the formula described by Fisher and Maurer (1978), to determine the Stress Susceptibility Index (SSI). The Stress Intensity was calculated to the variables bulk density, total porosity, aeration porosity, juice sucrose yield percent, sugarcane yield and agroindustrial sugarcane yield.

\section{STATISTICAL ANALYSIS}

Average values of the bulk density, total porosity and the aeration porosity, juice sucrose yield percent of the sugarcane, sugarcane yield and the agro industrial sugarcane yield values with their standard errors were plotted by bars. To compare the significance level of the average values for all variables, the Student t test was used at the 5,0 percent significant level. The statistical analysis was done by using the Infostat software (Di Rienzo et al., 2013).

\section{RESULTS AND DISCUSSION}

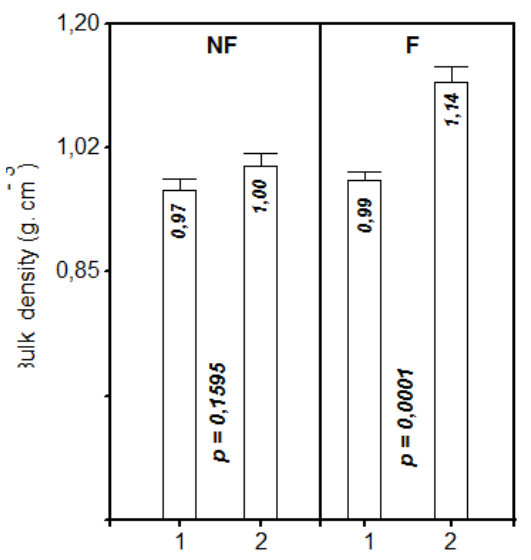

a)

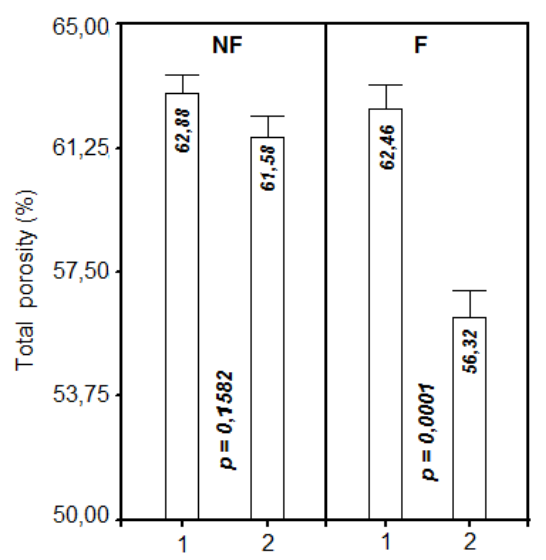

b)

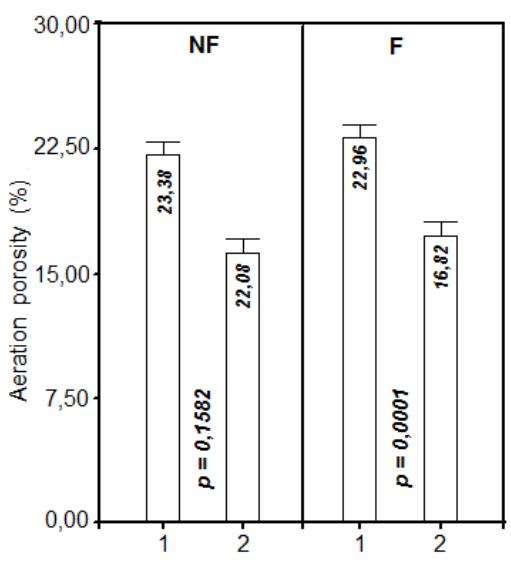

C)

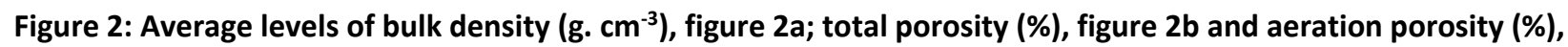
figure 2c, in non flooded conditions (NF) and in flooded conditions (F) in the soil, at the beginning (1) and at the end (2) of the experiment. Note: If $p \leq 0,05$ indicate significant differences to 0,005 percent of probability applying the student $t$ test.

The variations in the bulk density, total porosity and the aeration porosity in flooded and in not flooded conditions is shown in figure 2, 3 and 4, at the beginning and at the end of experiment. In not flooded conditions, the bulk density showed a slight increment (since 0,97 to $1,00 \mathrm{~g}^{-\mathrm{cm}^{-3}}$ in figure 2a), perhaps as a consequence of the anthropic factor, for their presence unavoidable for the take of samplings, which increase the degree of soil compactation, but without significant differences. In general in not flooded conditions there were not significants differences at the beginning and five month later in the three physical soil variables studied, bulk density, total porosity and the aeration porosity.

In the flooded soil conditions, in presence of the same anthropic conditions that the non flooded soil, the apparent density it was increased almost to twice (since 0,99 to $1,14 \mathrm{~g} . \mathrm{cm}^{-3}$ in figure 2a), as much in comparison with the non flooded soil condition, with significant statistical 
difference, that which originated in equal sense descents bigger of the porous total percentage (total porosity) and of the porous space full with air (aeration porosity), which resulted in important decreased in the total percentage of pores (total porosity) and pore space occupied by air (aeration porosity), unlike total porosity it includes cracks that are very common in these types of soil (Cid, 1992).

There is a narrow relationship between the soil porosity levels and their susceptibility to tolerate erosive processes. Rivera (1999), when evaluated the susceptibility and prediction of the erosion in soils from Colombia coffee area, demonstrated that when total porosity increased, the susceptibility of the soil erosion decreased.

The soil aggregate stability is defined as its persistence in front of some destructive forces, it can be climatic and other soils factors (Kay and Angers, 2000). The soil aggregate stability is determined, among other things, by the type and clay content; the moisture tension (Hartge, 2000), and their persistence in the time possesses environmental effects in the soil conservation (Brady and Weil, 2000).

Patrick and Mikkelsen (2002), encountered that increments in the soil apparent density originated decreased in the total porosity, it was attributed to a descent of the soil total volume not occupied by solids, causing reductions in the quantity of macroporous or non capillary porous. Cooder (2004), demonstrated that the soil flooding alters the soil structure, destroys the aggregates and it makes descend them in the soil profile, diminishes the cohesion, dissolveed the metal organic cover and it disperses the soil clays particles.

Contrary to the texture, the soil structure is susceptible to the changes by the man's action (Hartge, 1984). Variations in the soil structure affect the aeration, the infiltration speed and the soil permeability (Villar and Ferrer, 2005). About the relationship between the soil moisture level and the apparent density, Heuscher et al (2005), aided by multiple regressions and evaluated physical and chemical properties to estimate the apparent density, encountered among other aspects that the soil moisture level explained more than $30,0 \%$ of the total variation that took place in the soil apparent density studied.

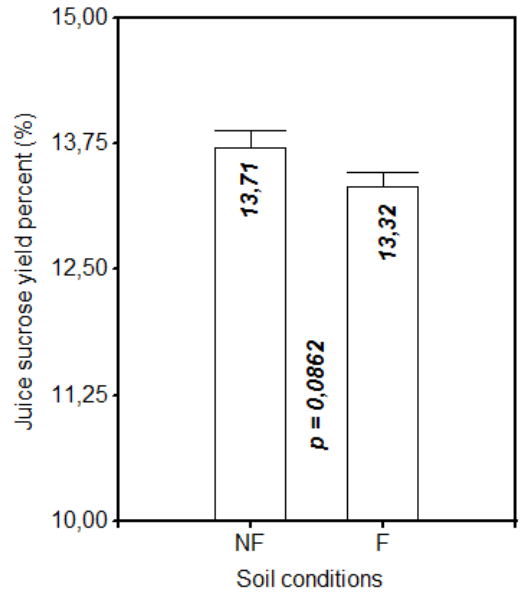

a)

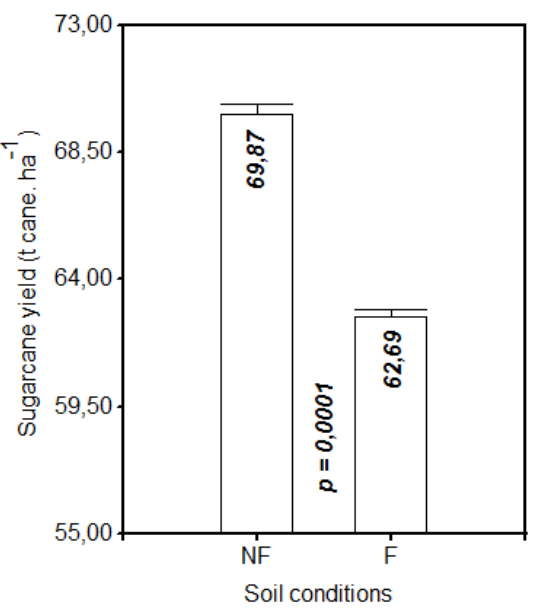

b)

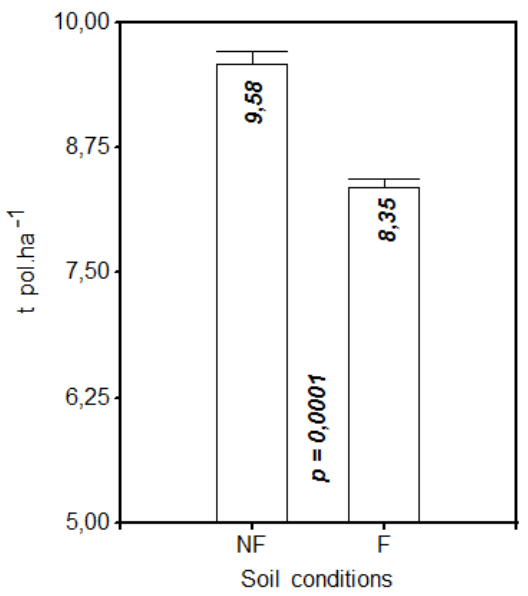

c)

Figure 3: Average levels of juice sucrose yield percent (\%), figure 3a; sugarcane yield (tcane.ha ${ }^{-1}$ ), figure $3 \mathrm{~b}$ and the agro industrial sugarcane yield (tpol.ha ${ }^{-1}$ ), figure $3 \mathrm{c}$, in the c90-469 cuban sugarcane variety planted after finished the experiment in non flooded conditions (NF) and in flooded conditions (F) in the soil. Note:lf $p \leq 0,05$ indicate significant differences to 0,005 percent of probability applying the student $t$ test. 
The influence in the sugarcane yield and in the sugarcane agroindustrial yields in sugarcane variety C90-469 planted after five months later of flooded concluded is shown in the figure $3 a, b$ and $\mathrm{c}$. In the figure $3 \mathrm{a}$ it was demonstrated that the alterations caused by frequents flood periods for five months modified soil physical properties as the apparent density, total porosity and porosity of aeration in a soil classified as a Vertisol, but this conditions not caused a significant decrease in the sucrose concentration in the stalks juice in c90-469 variety. However the disturbances caused by soil flooding effect provoked in these three physical properties after five months, reduced significantly sugarcane yield, since 69,87 until 62,69 $\mathrm{t} \mathrm{cane.ha}^{-1}$ (Fig. 3b) and the reduction of the sugarcane agroindustrial yields, since 9,58 until $8,35 \mathrm{t} \mathrm{pol.ha}^{-1}$ (Fig. 3c) These results could be associated to the significant reduction in the soil porous spaces, which reduced the aerobic environment of the soil, affecting the normal roots growth and development in plants, when increasing the soil apparent density and diminished the total porosity and aeration porosity.

Waterlogging has particularly profound effect on the crops. Shattering of capillary pores, trimming down void ratio, devastation of soil aggregates and heading off clay particles, are caused by waterlogging in Sweet sorghum (Sorghum bicolor L.) (Ammara and Shumaila, 2012).

Soil bulk density is defined as a ratio of dry mass to the total volume of soil (solids added pore space occupied by air and water) (Morales-Olmedo et al., 2015). Soil bulk density is intimately related to soil porosity, which is the volume of space within a soil filled with air and water. Chaudhari et al (2013) found negative correlation between porosity and soil bulk density.

Bulk density is an important soil property that affects soil porosity. The porosity of a soil is inversely related to the soil bulk density, Li and Shao (2006) stated that soil bulk density was negatively correlated with total porosity, similar correlation of total soil porosity and bulk density have been showed by Fahmi et al (2014). The soil porosity is intimately related to soil permeability, increasing pore within soil particle increases soil permeability (Fahmi et al., 2014).

Normally, when more than $90 \%$ of the porous space in the soil is full of water, lack of aeration is a serious impediment to root growth due to low oxygen availability (Dexter, 1988; Cook and Knight, 2003), since the water blocks the gas diffusion pathways to and from the atmosphere (Kozlowski, 1997; Jackson and Colmer, 2005).

The movement of gases in the soil is a dynamic phenomenon in which gases are transported mainly by diffusion; the main parameter to consider is the gas diffusion coefficient in the soil, which depends on texture, structure, distribution, size and pores connectivity, and tortuosity (Moldrup et al., 2000; 2001). Thus, an increase in pores saturated with water decreases oxygen movement, since diffusion in water is 10000 times slower than in air (Moldrup et al., 2000; Nickum et al., 2010), producing an anaerobic environment in a few hours if the oxygen is consumed by the activity of microorganisms and roots (Drew, 1992; Nickum et al., 2010).

The optimal soil composition for plant growth should contain about $50 \%$ solid and $50 \%$ pore space. Within the pore space, the mixture of air and water should be close to 50:50; hence, $25 \%$ of the soil volume should be occupied by air (Morales-Olmedo et al., 2015). Gas diffusion is conditioned by the physical properties of the soil, among which soil porosity is one of the most important, especially the fraction with air (Hillel, 1980). In the majority of soils, microbiological activity and plant growth are seriously inhibited when the porosity with air decreases to less than $20 \%$ of the pore space, which is related to soil properties such as texture, structure, water content, mineralogy of clays and sodium adsorption relation (Pezeshki et al., 1996; Tete et al., 2015). 
The magnitude of waterlogging in the soil can be characterized through the soil porosity, oxygen diffusion rate, redox potential and the composition of gases in the soil. In some soils maintained at field capacity, the aeration is a limiting parameter for plant growth, and this can be a common problem in irrigation management (Morales-Olmedo et al., 2015).

Aggregate stability is a relative term used to describe the resistance of a soil's structure to destructive forces such as dispersion, raindrop impact and slaking (Six et al., 2000). Bronick and Lal (2005), stated that aggregates are formed through the combination of mineral particles with organic and inorganic substances.

Soil waterlogging decreased soil aggregate stability throught swelling of colloids, DeCampos et al (2009) was also reported that soil waterlogging decreased soil aggregate stability and increased dissolution of cementing agents such as iron oxide. Furthermore soil waterlogging decreased oxygen availability, subsequently restricted the activity of microorganisms decomposer, in which microorganisms activity in soil promotes soil aggregate formation (Tang et al., 2011). Aggregate stability were affected by soil texture, predominant type of clay, extractable iron, and extractable cations (Li and Shao, 2006).

In Addition, lower aggregate stability due to soil waterlogging may explain with increasing water aggregate in unstable condition. Ponnamperuma (1984), stated that soil waterlogging destroys aggregate, this condition caused by aggregates are saturated with water. Sudjianto et al (2011) concluded that swelling of clay linearly increases with the increasing of water content.

In fine textured soils, the percentage of space with air tends to decrease when they are poorly structured, since clays have many small, discontinuous pores and retain water more easily than soils with coarser texture. Thus, plants tend to suffer oxygen limitation more frequently in clay soils in spite of their greater total porosity (Sojka and Scott, 2000). When a large amount of water is applied to the soil, and the texture is fine with a tendency to compaction or hanging strata that impede drainage, water is retained for a longer time, producing extended saturation of the pore space. In this first stage, the immediate consequence of inundation is the blockage of gas interchange with the atmosphere and extreme slowing of atmospheric interchange with the gases in the water, especially oxygen (Morales-Olmedo et al., 2015). The Vertisol soil is a clay soil.

Increasing water content decreases aeration. The effect of water on this parameter is intensified by increases in bulk density and/or the presence of small pores. Modification of these factors also affects the geometry of the pores, producing a decrease in macropores and an increase in micropores (Letey, 1985). Excess water generated by poor irrigation management, soils with low permeability, poor drainage, fine textures and poorly structured soils with discontinuous pores may facilitate the rapid and permanent saturation of soil pores (Morales-Olmedo et al., 2015).

One of the main soil function is to provide a medium for plant growth; thus, modifications of its physical and chemical characteristics have a great impact on the development of the root biomass and consequently on plant vegetative development (Pierret et al., 2007). The soil should have adequate proportions of water and air in the optimal range for the physiological performance of the plants. This balance may be altered by both natural and anthropic factors (Morales-Olmedo et al., 2015). Human related causes include poor irrigation management and soil compaction, while natural flooding are caused by excessive rain (Irfan et al., 2010). In both cases soils with high clay content and/or compaction due to agricultural practices are susceptible to soil waterlogging (Morales-Olmedo et al., 2015). 
Table 1: Stress Intensity (\%) of the bulk density, total porosity, aeration porosity, juice sucrose yield percent, sugarcane yield and the agroindustrial sugarcane yield. Non flooded conditions (NF), flooded conditions (F) and Stress Intensity (SI).

\begin{tabular}{c|c|c|c|c}
\hline Evaluations & NF & F & Dif. & SI (\%) \\
\hline Bulk density $\left(\mathrm{g} . \mathrm{cm}^{-3}\right.$ ) & 1,00 & 1,14 & $+0,14^{*}$ & 14,0 \\
Total porosity (\%) & 61,58 & 56,32 & $-5,26$ & 8,54 \\
Aeration porosity (\%) & 22,08 & 16,82 & $-5,26$ & 23,82 \\
Juice sucrose yield percent (\%) & 13,71 & 13,32 & $-0,39$ & 2,84 \\
Sugarcane yield (t cane.ha-1) & 69,87 & 62,69 & $-7,18$ & 10,27 \\
Agroindustrial sugarcane yield & 9,58 & 8,35 & $-1,23$ & 12,84 \\
(t cane.ha-1 & & & & \\
\hline
\end{tabular}

The flooded soil condition, caused an increase in the time of the bulk density with a difference in positive values of $+0,14 \mathrm{~g} . \mathrm{cm}^{-3}$, with a relative increase in the bulk density of $14,0 \%$. However for total porosity and aeration porosity there was a reduction in the time in the soil porosity and in the aeration porosity in $8,54 \%$ and $23,82 \%$ respectively. The alteration of these soil physical properties due to excess water in the soil conditions also affect the normal development of C90-469 sugarcane variety, assessed with a agroindustrial relative loss of 12,84 $\%$, followed by $10,27 \%$ loss on sugarcane yield, while the minor effects of the stress intensity was in the juice sucrose yield percent from the stalks, with a relative loss of $2,84 \%$ (Table 1 ).

The bulk density of the waterlogged soils somewhat increased, particularly in the B2 horizon. The changes in the soil's structure can be considered a diagnostic feature of the locally waterlogged chernozems (Tishchenko et al., 2013), but Fahmi et al (2014), showed that the soil waterlogging decreased aggregate stability, soil particle density and bulk density, but in not long waterlogging period, when studied the influence of height waterlogging on soil physical properties of potential and actual acid sulphate soils.

The structure of soil is adversely affected by flooding. This is characterized by breakdown of aggregates as a result of reduced cohesion, deflocculation of clay because of dilution of the soil solution, pressure of trapped air, stresses associated with uneven swelling, and destruction of cementing agents (Kozlowski, 1985). There is drastic change in soil material properties like shear strength parameters and bearing capacity for design of civil engineering structure (Raut et al., 2014).

If the apparent density levels of a soil are stable in the time, it is a reflection of the stability of the soil ped, can affirm that the significant increase that takes place in their values in flooded soil conditions, is direct consequence of the destruction of the soil ped by effect of the flood. And, if the excess of water in the soil increases the apparent density and it diminishes the total porosity, the volume occupied by air is affected, inside which the oxygen is present. Decreases in the content of this gas, begin to affect the cellular respiration process, which reduces in the same proportion the cells energy state in the roots (Stefano and Marras, 2006), affecting the water uptake processes and the soil nutrient level with direct consequence to the normal vegetative growth, vegetative development and a significant reductions in the agricultural yields.

By similar edaphoclimatic conditions with the Cauto River Valley, of the Granma province, Cuba, recommends the following actions to control floods, described by (Mahabaleshwara and Nagabhushan, 2014). 
1. Sound watershed management through extensive soil conservation, catchment area treatment, preservation of forests and increasing the forest area and construction of check dams.

2. Desilting at the selected zones along the river course.

3. Protecting the original river course without any habitation and cultivation.

4. Study of silt concentration and its accumulation phenomenon.

5. Monitoring the bed levels, width of river, alignment of course and acting for restoration to possible extent.

6. Adequate flood cushion to be provided in the storage structures.

The first is to applied a good drainage to prevent waterlogging (Valipour, 2014). Other researchers suggest after waterlogging soil conditions, apply organic matter. Organic matter application influences soil physical properties such as soil structure, bulk density (Ruehlmann and Korschens, 2009) and soil porosity (Lucas et al., 2014) and in chemical properties as a nitrogen and phosphorus transformation in the soil (Singh et al., 1988). If some crops as wheat is treated with extra nitrogen it can make a splendid recovery against the early waterlogging stress (Dong et al., 1983; Swarup and Sharma, 1993). Nowadays, introduce crop resistance to flooding conditions is one of the more important alternatives (Vartapetian and Jackson, 1997; Setter and Waters, 2003).

\section{CONCLUSIONS}

The region of the Cauto River Valley, in Granma province, Cuba, is an agricultural plain broad, in which Vertisols soils are predominants. In this type of soil, the physico-chemical characteristics and the predominant clay, increasing the soil flooding conditions, through processes of dilation - shrinkage characteristic of these soils, which may be intensified by heavy rain events, primarily in the hurricane season, which is from June 1 to November 30, in Cuba. In these soils, long periods of flooding alter the physical properties, by increase in bulk density, with the consequent decrease of the total porosity and aeration, affecting oxygen concentration in the soil, necessary for the normal development of the plants. The variation of these physical properties, when finished the soil flooding, affect the industrial and agricultural yields of sugarcane. Variations in physical properties caused for prolonged flooding stress in the Vertisol soil type, did not cause a significant decrease in stalks sucrose content of the sugarcane variety C90-469, it was the variable with a lower value of Stress Intensity or relative loss, while the variables with a greater percentage of Stress Intensity were the aeration porosity and agroindustrial yield, with relative losses of $23,82 \%$ and $12,84 \%$ respectively. The drainage must be always in mind as the main alternative to avoid flooding in these soils. Under these conditions it is advisable and necessary to implement improvements in the soil, such as the application of organic matter for its contribution to restore the soil structure, with favorable effect for aeration. Other, is the use of genotypes with tolerance to this kind of stress.

\section{BIBLIOGRAPHY}

1. ÁLVAREZ, B.A., DÍAZ, E. Caracterización de los suelos de la cuenca hidrográfica del Río Cauto, Revista Electrónica Granma Ciencia, v.4, n.2, p. 8- 13, mayo - agosto. 2000.

2. AMMARA, M., SHUMAILA, N. A. Review: Waterlogging effects on morphological, anatomical, 
physiological and biochemical attributes of food and cash crops. International Journal of Water Resources and Environmental Sciences, v.1, n.4, p. 113-120. 2012.

3. BANDYOPADHYAY, P.K., SAHA, S., MANI, P.K., MANDAL, B. Effect of organic inputs on aggregate associated organic carbon concentration under long term rice wheat cropping system. Geoderma, n.154, p. 379-386. 2010.

4. BRADY, N.C., WEIL, R.R. Elements of the nature and properties of soils, Prentice Hall, Upper Saddle River, New Jersey, USA, 559 pp. 2000.

5. BRONICK, C.J., LAL, R. Soil structure and management: a review. Geoderma, n.124, p. 3-22. 2005.

6. CHAUDHARI, P.R., AHIRE, D.V., AHIRE, V.D., CHKRAVARTY, M., MAITY, S. Soil bulk density as related to soil texture, organic matter content and available total nutrients of Coimbatore soil. International Journal of Scientic and Research Publication, n.3, p. 1-8. 2013.

7. CID, G. Efectos de lós fenômenos de contracción - dilatación sobre lãs transferencias de água y aire em suelos com arcillas dilatables, 116 pp. Tesis para optar por El grado científico de Doctor en Ciencias Agrícolas, I.I.R.D., La Habana. 1992.

8. CIGEA. Síntesis del diagnóstico de la desertificación y la sequía en Cuba. Caracterización del archipiélago cubano, Centro de Información, Gestión y Educación Ambiental, s/p. 2001.

9. COODER, K.D. Flood damage to trees. Extensión Resources, 15 pp., College of Agricultural and Environmental Sciences, University of Georgia. 2004.

10. COOK, F.J., KNIGHT, J.H. Oxygen transport to plant roots. Soil Science Society of America Journal, n.67, p. 20-31. 2003.

11. COSENTINO, D., CHENU, C., LE-BISSONNAIS, Y. Aggregate stability and microbial community dynamics under drying-wetting cycles in a silt loam soil. Soil Biology and Biochemistry, v.38, n.8. p. 2053-2062. 2006.

12. DAT, J., CAPELLI, N., FOLZER, H., BORGEAD, P., BADO, P.M. Sensing and signaling during plant flooding. Plant Physiology and Biochemistry, n.42, p. 273-282. 2004.

13. DE-CAMPOS, A.B., MAMEDOV, A.I., HUANG, C.H. Short-term reducing conditions decrease soil aggregation. Soil Science Society of America Journal, n.73, p. 550-559. 2009.

14. DEXTER, A.R. Advances in characterization of soil structure. Soil and Tillage Research, n.11, p. 199-238. 1988.

15. DI RIENZO, J.A., CASANOVES, F., BALZARINI, M.G., GONZÁLEZ, L., TABLADA, M., ROBLEDO, C.W. InfoStat, versión 2013, Grupo InfoStat, Facultad de Ciencias Agropecuarias, Universidad Nacional de Córdoba, Argentina. URL http://www.infostat.com. 2013.

16. DREW, M.C. Soil aeration and plant root metabolism. Soil Science, n.154, p. 259-268. 1992.

17. DRIESSEN, P., DECKERS, J., SPARARGAREN, O., NACHTERGAELE, F. Lecture notes on the major soils of the world. World Soil Resources Reports, n.94, 334 pp., FAO. 2001.

18. DONG, J.G., YU, Z.W., YU, S.W. Effect of increased ethylene production during different periods on the resistance of wheat plants to water logging. Acta Phytophysiol Sinica, n.9, p. 383-389. 1983.

19. FAHMI, A., SUSILAWATI, A., RACHMAN, A. Influence of height waterlogging on soil physical 
properties of potential and actual acid sulphate soils. Journal of Tropicals Soils, v.19, n.2, p. 2014: 77-83. 2014.

20. FISHER, R.A., MAURER, R. Drought resistance in spring wheat cultivars. I. Grain yield responses. Australian Journal of Agricultural Research, n.29, p. 897-917. 1978.

21. GAVANDE, S.A. Física de suelos. Principios y aplicaciones, 35 pp Ed. Limusa, S. A. de C.V., México. 1987.

22. GOEBEL M., BACHMANN, J., WOCHE, S.K., FISCHER, W.R. Soil wettability, aggregate stability, and the decomposition of soil organic matter. Geoderma, n.128, p. 80-93. 2005.

23. Grieve, A.M., Dunford, E., Marston, D., Martin, R.E., Slavich, P. Effects of waterlogging and soil salinity on irrigated agriculture in the Murray Valley: a review. Australian Journal of Experimental Agriculture, v.26, n.6, p. $761-777.1986$.

24. HARTGE, K.H. The influence of soil physical properties on the growth and yield of cultivated plants. Journal Indian Society of Soil Science, n.32, p. 595-602. 1984.

25. The effect of soil deformation on physical soil properties. A disscourse on the common background", en Horn, R., J. J. H. van den Akker, and J. Arvidsson (eds). Subsoil compaction. Distribution, precesses and consequences, pp. 32-43, Catena Verlag. Reiskirchen, Germany. 2000.

26. HEUSCHER, S.A., BRANDT, C.C., JARDINE, P.M. Using soil physical and chemical properties to estimate bulk density. Soil Science Society American Journal, n.69, p. 51-56. 2005.

27. HILLEL, D. Fundamentals of soil physics. Academic Press, Orlando, Florida, USA. 1980.

28. INICA. Normas y procedimientos del programa de mejoramiento genético de la caña de azúcar. Boletín No 1 Cuba \& Caña-INICA. Instituto Nacional de Investigaciones de la Caña de Azúcar. 315 pp. 2002.

29. IRFAN, M., HAYAT, S., HAYAT, Q., AFROZ, S., AHMAD, A. Physiological and biochemical changes in plants under waterlogging. Protoplasma, n.241, p. 3-17. 2010.

30. JACKSON, M.B., COLMER, T.D. Response and adaptation by plants to flooding stress. Annals of Botany, n.96, p. 501-505. 2005.

31. JORGE, H., MORALES, F., JORGE, I., GARCÍA, H. Catálogo de nuevas variedades de caña de azúcar. Publicaciones INICA. 105 pp. 2004.

32. KAY, B.D., ANGERS, D.A. Soil structure, en Summer, M. (ed). Handbook of soil science, pp. 229276, CRC Press, Boca Raton, Florida, USA. 2000.

33. KENNEY, S., POTTINGER, G., PLIMMER, F., POCOCK, Y. Flood risk and property. Impacts on commercial and residential stakeholders strategic. College of State Mangement. UK. ISBN-13: 978-1-904388-61-6. 194 pp. 2006.

34. KOZLOWSKI, T.T. Soil aeration, flooding, and tree growth. Journal of Arboriculture, v.11, n.3, p. 85-96, march. 1985.

35. KOZLOWSKI, T.T. Responses of woody plants to flooding and salinity. Tree Physiology Monograph, v.1, n.1, p. 1-29. 1997.

36. LAL, R. Erodibility and erosivity, pp.141-160, in Lal R(ed) Soil Erosion Research Methods. Soil Water Conservation Society. Ankey. I. A. 1994. 
37. LETEY, J. Relationship between soil physical properties and crop production. Advances in Soil Science, n.1, p. 276-294. 1985.

38. LI, Y.Y., SHAO, M.A. Change of soil physical under long term natural vegetation restoration in the loess plateau of China. Journal of Arid Environments, n.64, p. 77-96. 2006.

39. LUCAS, S.T., D’ANGELO, E.M., WILLIAMS, M.A. Improving soil structure by promoting fungal abundance with organic soil amendments. Applied Soil Ecology, n.75, p. 13-23. 2014.

40. MAHABALESHWARA, H., NAGABHUSHAN, H.M. A study on soil erosion and its impacts on floods and sedimentation. International Journal of Research in Engineering and Technology, v.03, n.03, p. 443-451. May. 2014.

41. MOLDRUP, P., OLESEN, T., SCHJONNING, P., YAMAGUCHI, T., ROLSTON, D.E. Predicting the gas diffusion coefficient in undisturbed soil from soil water characteristics. Soil Science Society of America Journal, n.64, p. 94-100. 2000.

42. MOldRUP, P., OleSEN, T., KOMATSU, T., SCHJONNING, P., ROLSTON, D.E. Tortuosity, diffusivity, and permeability in the soil liquid and gaseous phases. Soil Science Society of America Journal, n. 65, p. 613-623. 2001.

43. MORALES-OLMEDO, M., ORTIZ, M., SELLÉS, G. Effects of transient soil waterlogging and its importance for rootstock selection. Chilean Journal of Agricultural Research 75 (Suppl. 1) Aug, p. 45-56. 2015.

44. NICKUM, M.T., CRANE, J.H., SCHAFFER, B., DAVIES, F.S. Reponses of mamey sapote (Pouteria sapota) trees to continuous and cyclical flooding in calcareous soil. Scientia Horticulturae, n.123, p. 402-411. 2010.

45. ORTíZ, C.G., RIVERO, L.R. Retención de la humedad de los Vertisoles a partir de un nuevo concepto. Importancia para el riego y drenaje. II Conferencia Científica de Ingeniería Agrícola de la Habana. AGRING 2006. Disco Compacto. 2006.

46. PATRICK, W., MIKKELSEN, D.S. Plant nutrient behavior in flooded soil. Fertilizer technology and use (3rd Edition), pp 187-215, Soil Science Society of America, USA. 2002.

47. PEZESHKI, S.R., PARDUE, J.H., DELAUNE, R.D. Leaf gas exchange and growth of flood-tolerant and flood-sensitive tree species under low soil redox conditions. Tree Physiology, n.16, p. 453458. 1996.

48. PIERRET, A., DOUSSAN, C., CAPOWIEZ, Y., BASTARDIE, F., PAGES, L. Root functional architecture: A framework for modeling the interplay between roots and soil. Vadose Zone Journal, n.6, p. 269-281. 2007.

49. PMA. Análisis y cartografía de la vulnerabilidad a la seguridad alimentaria en Cuba. Programa Mundial de Alimentos en Cuba. Año 38. septiembre. 143 pp. 2001.

50. PONNAMPERUMA, F.N. Effects of flooding on soils. In: T. Kozlawski (Eds.) Flooding and Plant Growth; Physical Ekology. A series monographs, text and treatises. Academic Press Inc. Harcourt Brace Javanovich Publisher, USA, pp. 10-45. 1984.

51. RAUT, J.M., PANDE, P.B., GABHANE, M.V., BAJAD, S.P., KHADESHWAR, S.R. Effect of flood on soil and structure. International Journal of Research in Engineering and Applied Sciences, v.02, n.02, p. 106-109. July. 2014.

52. RUEHLMANN, J., KORSCHENS, M. Calculating the effect of soil organic matter concentration 
on soil bulk density. Soil Science Society of America Journal, n.73, p. 876-885. 2009.

53. REDDY, K.R., DELAUNE, R.D. The Biogeochemistry of wetlands: Science and applications. CRC Press. New York, USA. 779 p. 2008.

54. RIVERA, P.H. Susceptibilidad y predicción de la erosión en suelos de la ladera de la zona cafetera colombiana. Medellín (Colombia). Tesis en opción al título de Doctor en Aprovechamiento de Recursos Hidráulicos, 525 pp, Facultad de Minas, Univ. Nac. de Colombia sede Medellín. 1999.

55. SETTER, T.L., WATERS, I. Review of prospects for germplasm improvement for waterlogging tolerance in wheat, barley and oats. Plant and Soil, n.253, p. 1-34. 2003.

56. SHARMA, D.P., SWARUP, A. Effect of short term waterlogging on growth, yield and mineral composition of wheat in sodic soils under field condition. Plant and Soil, n.107, p. 137:143. 1988.

57. SINGH, Y., SINGH, B., MASKINA, M.S., MEELU, O.P. Effect of organic manures, crop residues and green manure (Sesbania aculeata) on nitrogen and phosphorus transformations in a sandy loam at field capacity and under waterlogged conditions. Biology and Fertility of Soils, n.6, p. 183-187. 1988.

58. SIX, J., ELLIOTT, E.T., PAUSTIAN, K. Soil structure and soil organic matter: II. A normalized stability index and the effect of mineralogy. Soil Science Society of America Journal, n.64, p. 1042-1049. 2000.

59. SOIL SURVEY STAFF: Claves para la Taxonomía de Suelos, 306 pp., Colegio de Postgraduados, Chapingo, México. 2003.

60. SOJKA, R.E., SCOTT, H.D. Aeration measurement. p. 27-29. In R. Lal. (ed.) Encyclopedia of soil science. Marcel Dekker, New York, USA. 2000.

61. STEFANO, M., MARRAS, A.M. Adaptative response of vitis root to anoxia. Plant Cell Physiologyl, v.47, n3, p. 401-409. 2006.

62. SUDJIANTO, A.T., SURYOLELONO, K.B., RIFA'I, A., MOCHTAR, I.B. The effect of water content change and variation suction in behavior swelling of expansive soil. International Journal of Civil and Environment Engineering, n.11, p. 11-17. 2011.

63. SWARUP, A., SHARMA, D.P. Influence of to dressed nitrogen in alleviating adverse effects of flooding of growth and yield of wheat in a sodic soil. Field Crops Research, n.35, p. 93-100. 1993.

64. TANG, J., MO, Y., ZHANG, J., ZHANG, R. Influence of biological aggregating agents associated with microbial population on soil aggregate stability. Applied Soil Ecology, n.47, p. 153-159. 2011.

65. TETE, E., VIAUD, V., WALTER, C. Organic carbon and nitrogen mineralization in a poorly-drained mineral soil under transient waterlogged conditions: an incubation experiment. European Journal of Soil Science, n.66, p. 427-437. 2015.

66. TISHCHENKO, S.A., BEZUGLOVA, O.S., MOROZOV, I.V. Specificity of the physical properties of soils in locally waterlogged landscapes in the lower reaches of the Don River. Eurasian Soil Science, v.46, n.3, p. 297-302, march. 2013.

67. VALIPOUR, M. Drainage, waterlogging, and salinity. Archives of Agronomy and Soil Science, 
v.60, n.12, p. 1625-1640. 2014.

68. VARTAPETIAN, B.B., JACKSON, M.B. Plant adaptations to anaerobic stress. Annals of Botany, n. 79, p. 3-20. 1997.

69. VILLAR, M.M., FERRER, F.A. Técnicas de medida y control del agua en el suelo. Agua y Agronomía, n1, p. 25-86. 2005.

70. WESSELING, J. Crop growth and wet soils. Van Schilfgaarde, Jan (editor). Drainage for agriculture. p. 7-37. American Society of Agronomy, Madison, WI. 1974.

71. YONG, M.S., JAE, D.S., GEON, Y.J., DOO, H.K., MOO, E. P. Effect of flooding and soil salinity on the growth of yam (Dioscorea batatas) transplanted by seedling of aerial bulblet in saemangeum reclaimed tidal land. Korean Journal of Soil Science and Fertilizer, v.44, n.1, p. 814. 2011.

72. ZHANG, Z.B., PENG, X., WANG, L.L., ZHAO, Q.G., LIN, H. Temporal changes in shrinkage behavior of two paddy soils under alternative flooding and drying cycles and its consequence on percolation. Geoderma, n.192, p. 12-20. 2013. 